\title{
The Prevention of Student Delinquency through Three Education Centre Communication
}

\author{
Suranto Aw, Mami Hajaroh, Chatia Hastasari \\ Universitas Negeri Yogyakarta, Jl. Colombo No.1 Yogyakarta 55281, Yogyakarta, Indonesia
}

\begin{abstract}
The aim of this research is to reveal the efforts of preventing student delinquency through communication within the three education centers (school, family, and community). Three education center communication is a process of interaction performed by the educational stakeholders as a strategic effort to increase the role of schools, families and communities in educational management. The informants of this research were students, teachers, parents, and community leaders. Data were analyzed using interactive analysis which consisted of four stages, namely: data collection, data reduction, data display, and conclusion drawing / verification. The results of the research show that the efforts include revitalizing the three education center communication systems pertaining to the role in delivering and receiving messages in the school, family, and community environment.
\end{abstract}

Keywords -student delinquency, communication, school, family, community.

\section{Introduction}

The juvenile delinquency problems such as vandalism, brawl, motorbike gang, smoking, alcohol drinking and street children still mark the educational sector in Indonesia.

DOI: $10.18421 /$ SAR34-01

https://doi.org/10.18421/SAR34-01

Corresponding author: Suranto Aw,

Universitas Negeri Yogyakarta, Jl. Colombo No.1 Yogyakarta 55281, Yogyakarta, Indonesia.

Email: suranto@uny.ac.id

Received: 09 October 2020.

Revised: 07 December 2020.

Accepted: 14 December 2020.

Published: 30 December 2020.

(cc) BY-NC-ND (C) 2020 Suranto Aw, Mami Hajaroh \& Chatia Hastasari; published by UIKTEN. This work is licensed under the Creative Commons AttributionNonCommercial-NoDerivs 3.0 License.

The article is published with Open Access at www.sarjournal.com
In terms of quality and quantity, the level of delinquency committed by adolescents has reached a worrying degree. The results of the study [1] reveal that $46 \%$ of the 15,000 drug cases during the last two years in Indonesia involved students or adolescents. In 2016, there were 157 cases of student delinquency, and it increased to 183 cases in 2017. Furthermore, the results of the study [2] report the findings that, viewed from the geographical spread, student delinquency mostly occurred in big cities such as Jakarta, Surabaya, Semarang, Medan, Bandung and Yogyakarta. The frequency of delinquency in private schools is higher than that in public schools.

The moral degeneration has triggered the student delinquency. This moral decline is caused by the internal and external factors of the students. Internally, it deals with the low motivation of students to understand moral values. While externally, it correlates with the decreasing family commitment in maintaining moral quality [3]. Several studies indicate that the family of student delinquency actors are inharmonious such as single parent family, broken homes, and a family with economic problems [4]. Another study reveals that student delinquency and school climate are impacted by the internal and external factors which include peer influence, low student enrolment in schools, application of regulations that are irrelevant to the needs of adolescents, and low achievement opportunities for students [5]. [6] states, "negative relationships within the classroom, both with peers and teachers, can be very stressful for adolescents and are often found to be associated with a variety of negative outcomes". [7] concludes that juvenile delinquency occurs due to closed social relationship, and they tend not to be open to other views, especially those who have different beliefs and cultures.

The student delinquency can be prevented using many different strategies, for example: (1) preemptive efforts by stopping such actions from happening at an early phase, (2) preventive efforts by reducing the chances (opportunities) of its spread, and (3) repressive efforts by performing legal action for those who obviously violate the law. [8] suggests 
some strategies to prevent student delinquency that include: developing violence prevention curricula, counselling strategies, and implementing strict sanctions against violators of the school's zero tolerance policies that exclude high-risk students from the schools. Further more technically, some schools apply security practices such as installing metal detectors and security cameras.

The prevention of student delinquency which involves three relevant educational micro-systems (school, family, and community) within a communication system has provided a promising hope. The aspects that need to be considered regarding the communication process of preventing student delinquency may consist of: (1) in schools, the psychosocial environment (school and class) and changes in school organization; (2) in family, the educational level of parents and the conditions of the family environment; (3) in society, positive connections to adults, and community intervention against adolescents. Based on this view, there are three components of communication actors that contribute to the improvement of the education quality, namely school, family, and community. Those three components are then better known as the three education centres. The collaboration and communication between schools, families and communities need to be intensified. Ideally, an effective communication system should be developed to support schools in producing educated and ethical generations as well as to eradicate student delinquency behaviour [10].

The contribution of the three education centres in preventing the increase of student delinquency is enhanced by the commitment of the Indonesian Government. The government has developed and implemented various policies to encourage schools to produce graduates who have great achievement and noble character. This commitment is reflected in the Strategic Plan document of the Ministry of Education and Culture 2015-2019, which include (a) the increasing transparency of public information and public communication on educational and cultural development; (b) the increasing public access to educational and cultural development; and (c) the increasing education and learning implementation to produce excellent graduates [11], [12]. In addition, the Presidential Regulation No. 7/2005 concerning the National RPJM addresses the importance of schools, families and communities in the concept of School Based Management (SBM). In essence, SBM is one of the policy directions in the management of education which emphasizes achievement and noble character, increasing the role of schools and the community (stakeholders) in the educational management.

\section{Literature Review}

Three education centre communication is a forum which serves for information exchange between the three education centres, namely schools, families, and communities. These three education centres act as sources of information to guide students to avoid various forms of deviant behaviour i.e. delinquency. [13] explains that system is a firmness or whole complex or organized, a set or combination of components that form a complex and complete firmness. Based on this explanation, the fundamental concept of communication systems which becomes the focus of this research is the theoretical concept of the three education centre communication processes and procedures which involve communicator components, messages, channels, communicants, and effects as well as the procedures for communicating and speaking in a socio-cultural setting. This is in line with the view of [14], "in a tentative scheme of the field, rhetorical, semiotic, phenomenological, sociocultural, and critical tradition are distinguished by characteristic ways of defining communication system".

The effects of communication include the changes experienced by the audience, which consist of cognitive, affective and behavioural changes. If communication keeps going, there will be interactions, namely mutual influence between one individual and another. In general, communication serves to convey information and influence the individual psychological behaviour [15]. Furthermore, [16] states that there are four communication approaches that can encourage the behavioural changes of the target audience, namely exchanging information, instructions, persuasion and dialogue.

The focus of this research deals with the efforts to uncover the strategies to prevent student delinquency through a communication system that involves various education stakeholders, which include the three education centres (schools, families, communities) as sources of information. Based on several literatures, two models of communication approaches have been identified, namely: (1) a structural model that is bureaucratic, one-way top down, formal, coercive, instantaneous, not rooted in community members; (2) a cultural model which is based on the development of community and school culture, bottom-up, informal, arises from awareness and commitment, rooted in community members, and permanent [17]. Meanwhile, other theories suggest formal and non-formal communication models. Formal communication is structured, focused, and offers a symbolic interaction on behalf of the institutional status of the communication actors. Meanwhile, informal communication is unstructured, 
the dialogue process is freer or more flexible which can last a long time although it may be unfocused. Interaction prioritizes intimacy or establishing a close relationship [18].

The family environment is the primary and first environment for youth. In a nuclear family, the first figure who communicate with adolescents are parents. Children begin to recognize values to guide their attitudes and actions from their parents. Education implemented in the family offers a very important function. Communication practices within the family functions to develop children's personality and instil norms that include courtesy, respect for parents, respect for others, discipline, and so on. Law No. 4 Year 1999 regarding Child Welfare states that, "Parents are the first figures who have responsibility to realize children's welfare both spiritually, physically and socially". This law stipulates that the responsibilities of parents and family are the main components in the educational process for children. This indicates that there is a great demand for the parent's role in educating and maturing children.

[19] suggests that cultural and participatory communication systems should be designed by considering social, cultural, political, legal, and economic norms that derive from national, organizational, and personal culture.

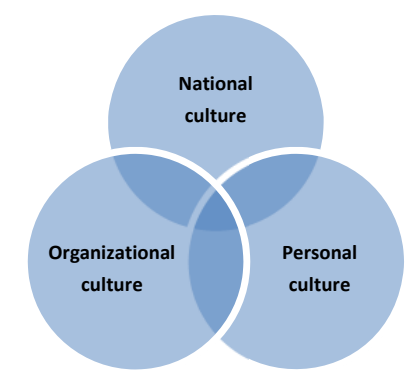

Figure 1. Sources of values (Kitty O. Locker, 2004)

The implementation of a communication system which employs a cultural approach is perceived as a more suitable approach in the communication process of the three education centers. However, this is not intended to replace the structural approach, because the structural approach also plays a big role. [20] explains the challenges of understanding the various goals and interests of the society, "The challenge is to understand the multiple goals and dimensions of the field, to acknowledge the principle of recursively in all communicative practices".

The theory of Biology communication examines the process of communication, which starts from the interaction process between specific parts of the left and right brain to produce biological reactions in the form of changes in attitudes and behavior in accordance with the message exposure [21], [22]. The research results of [23] show that communication develops from the conscious and subconscious level to simple and complex messages, "communication developed at conscious level, for superficial messages, and substantiated at unconscious level through informational compressions, systematizations and abstractions". Furthermore, [25] argues that, when communicating, each party does not only exchange information but also exchange knowledge and experiences. The result of communication is the acquisition of new knowledge and experiences exposed by others. Meanwhile, [26] explains that the cognitive psychology paradigm is a new paradigm of the conception of humans. Humans are no longer viewed as creatures that react passively to the environment, but as creatures who always try to understand their environment.

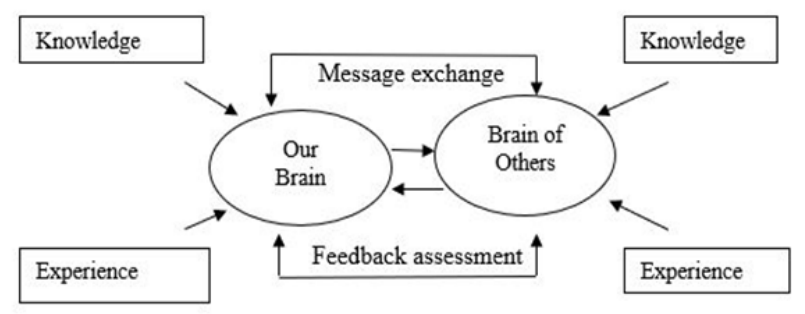

Figure 2. Perspective of Biology communication

The key point for student delinquency prevention efforts starts from improving the care of the three education centers to become a source (source: S) that creates and disseminates information (message: $\mathrm{M}$ ), choose the right channel (channel: C) so that it can influence the attitudes and behavior of students as recipients (receiver: R). The figures within the three education centers as sources of information must have good communication skills and positive attitudes. The message that is communicated must be adjusted to the rules and values that exist at the individual, organizational and group levels. This concept is relevant to the S-M-C-R communication model, where communication process involves Source, Message, Channel, and Receiver components. Each component sustains each other as a system to achieve the desired goals.

\section{Research Methods}

This research employs a qualitative method. This method offers a thorough understanding and interpretation of the meaning of facts, terms, concepts, and assumptions in the field that are relevant to the research. [28] explains "Qualitative research is a field of inquiry in its own right. It crosscuts disciplines, fields, and subject matter. A complex, interconnected family of terms, concepts, and assumptions surround the term qualitative research". The research setting was determined purposively based on the research objectives to study 
and analyze the prevention of student delinquency through the implementation of the three education center communication processes in public and private high schools.

The research data were collected utilizing interview and observation techniques. The informants were selected by considering the relevance of their expertise and authority to the research objects. After going through the considerations, the researchers determined informants who represented teachers, counselling teachers, homeroom teachers, students, parents, community leaders, and police officers. To increase the degree of the data validity, the researchers extended the research period and performed a triangulation technique. The extension of the research period can be used to examine the consistency of data and to give more opportunities for researchers to study the existing habits, and compare data from observations and interviews at one time with another. [24] explains, "triangulating data is comparing and cross-checking the consistency of information derived at different times and different means within qualitative methods". Data analysis techniques employed an interactive analysis model that consisted of four steps: data collection, data reduction, data display, conclusion: drawing / verifying [25].

\section{Results and Discussions}

The results of analysis on the research data collected through interviews and observations show that there have been various attempts to revitalize the functions and roles of communication between the three education centers (schools, families, and communities). The revitalization in this research is defined as an effort to strengthen the communication of the three education centers as an important and strategic activity in order to prevent student delinquency. The communication process is carried out in the school, family and community environment.

The revitalization of communication in the school environment is realized by strengthening the credibility of principals and teachers before the students. In this case, the principals and teacher's role as communicators while students' subject role as communicants or beneficiaries. In this communication process, school principals and teachers act as communicators who deliver messages to prevent student delinquency in the form of policy internalization, socialization of school regulations, role modeling, and empowerment.

In the eyes of the students, the school principal is perceived as a highly credible communicator. The messages delivered by the principal are considered by students as policies and rules that must be implemented. The school's policies are informed using formal media in the form of decrees, circulars, or announcements which are shared at meetings or flag ceremonies. In addition, school policies and regulations are also communicated by utilizing poster posted at strategic spots in the school.

The communication model between teachers and students is the main media for schools to prevent student delinquency. In this case, there are three types of teachers viewed from their duty: (1) Guidance and Counseling teachers, (2) Homeroom teachers, and (3) Subject teachers. The counseling teachers act as a friend-like teacher who provides assistance for the students to deal with difficulties both academic and non-academic. The homeroom teachers are responsible for ensuring the smooth learning process and creating a conducive atmosphere. In addition, subject teachers have a duty to deliver the teaching materials and values in accordance with the subjects they are teaching.

In the three education center communication system within the family environment, parents play roles as communicators to deliver messages that encourage the development of children's noble characters. Viewed from the time duration, communication within the family provides the longest duration compared to schools and communities. Children's behavior patterns are strongly influenced by the communication patterns developed in the family on a daily basis. The results of interviews with teachers indicated that some students who were identified as naughty at schools mostly came from inharmonious families. For example, their parents' divorce, move to other cities to get better job, do not care enough and provide a full authority for school to educate their children's and so on.

The three education center communication system places the community as an important actor who delivers messages to students. Communication in society offers a higher complexity. This is due to various sources of information ranging from community leaders, peers, and media users, especially social media, who may upload huge information. The three education center communication system positions the community as an important actor who delivers messages to students. Many students are involved in various acts of delinquency due to negative influences exposed by their society. The research results show various model of community behavior within the framework of a communication system to prevent student delinquency.

A lot of students perform delinquency because of negative impacts from the society. Therefore, based on the results of interviews with community leaders, 
the revitalization of communication is carried out by increasing the role of social institutions such as Karang Taruna (Youth Organization), Rukun Warga (Community Unit), and Rukun Tetangga (Neighborhood Unit) as communicators who deliver educational messages for teenagers.

The expected ideal condition is that the communicators have adequate expertise to provide solutions to various problems, but in fact almost all research informants (parents) admit their low expertise. This gap indicates that one of the communication barriers is the low skills of parents in communicating and mentoring. The low skill of communicators contributes to their failure in influencing the communicants. This is because the communicators become a source person to whom questions and problems are addressed. In this case, the communicants really expect to get solutions of their problems from the communicators.

Referring to the SMCR communication model, some key points in the three education centers communication system are (1) the sources of information consist of schools (teachers), family (parents), and the community, (2) the content of the message deals with useful information for preventing student delinquency, (3) the channels or media used comprise of learning, books, face-to-face meetings, social media, mentoring, guidance, and so on, (4) message receivers are high school students who are expected to give responses in the form of avoiding delinquency practices.

The concept of the three education center communication system places schools (teachers), families (parents), and the communities as sources of information. The communication between the three education centers needs to be revitalized, adapted to the characteristics of students, media, and sociocultural norms. In this system, students as learning subjects serve as beneficiary communicants. The delivery of this message can be realized by internalizing regulations and policies, awareness, role modelling, mentoring, and empowerment. The media used needs to be adjusted to the characteristics of students, for example through the learning process, socialization, consultation, and advocacy. While the purpose of communication is creating conditions and promoting student empowerment to prevent student delinquency. [26] emphasizes that empowerment is an effort to increase the ability of human resources to deal with various threats and challenges in life.

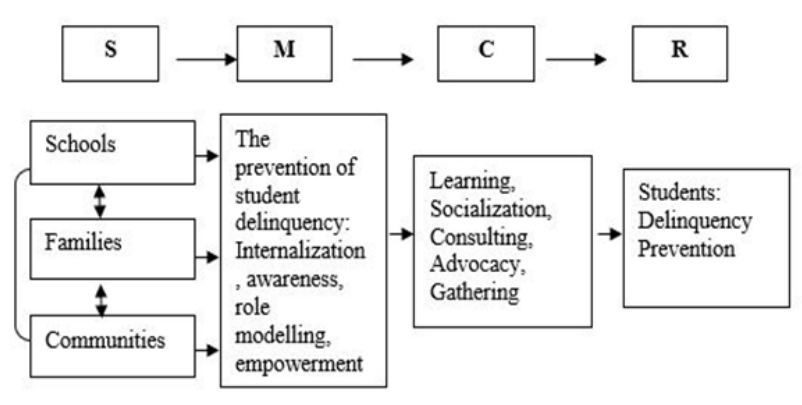

Figure 3. Communication of Three Education Center

Some relevant studies conclude various views and recommendations which deal with the role of the three education centres in preventing the student delinquency. Various research findings are explained as follows: (1) Types of student delinquency which can be easily identified include verbal abuse such as using words and sentences to curse, snap, mock, threaten, harass, blaspheme, slander, and so on; (2) The attitudes or character values which can prevent radical understanding and delinquency of high school students have not been well developed; (3) Realizing quality education may involve the role of family, school, and community; (4) Strengthening moral education or character education in the present time is very relevant in preventing and overcoming radicalism; (5) The need for transforming the school's function from centralized to decentralized, schools have the autonomy to create as centres of education and culture; (6) Understanding learning materials can be in various types of actions or in developing the behaviour of students. Types of behaviour include habits, ways of acting, skills, perceptions, memorization, attitudes, feelings, and so on [27].

In some schools, the communication system between the school, family and community through the school committee is still seeking for the appropriate model. Various models of the three education centre communication systems in some schools have not provided an effective system to help schools produce graduates with superior achievements and noble characters. The communication model between schools and families through school committee forums tends to focus on discussing the physical development of schools. [28] Emphasizes the importance of the family and society role, "Through family and society, children learn to respond to others, know themselves, and simultaneously learn to manage their emotions. The management of this emotion is influenced by the communication models practised in the family and society, especially the attitudes of adults in educating and caring for the children. 
Through family, children learn to respond to others, get to know themselves, and at the same time learn to manage their emotions. The management of this emotion is affected by the communication patterns applied in the family, especially the attitude of parents in educating and caring for their children. In addition, it is also necessary to pay attention to the influence of social media which become the main media of communication in society. [29] states that "Mobile technology and social media exert a substantial impact on our society and daily lives". A similar view is expressed by [30], that social media and the internet have become the main media which substitute the national newspapers, "Mass media are said to report issues that are related to the agenda and have set to influence the public's opinion." Furthermore, [9] explains about the communication in the family and public space, "connection of private familial spheres to larger public discourses and structures; and inherent openness to critique, resistance, and transformation of the status quo".

\section{Conclusion}

Based on the research results and discussions, it can be summarized that the three education centres communication system is a strategic forum to guide students to avoid various forms of deviant behaviour, especially delinquency. Students are invaluable assets for the nation and state. They are potential future leaders of the nation, so they need to be equipped with excellent personal capacities in the form of academic abilities and noble character. In the three education centre communication system, the family environment becomes the main and first environment for adolescents.

\section{References}

[1]. Aini, L. N. (2017). Hubungan Pola Asuh Orang Tua dengan Kenakalan Remaja di RW V Kelurahan Sidokare Kecamatan Sidoarjo. Jurnal Keperawatan dan Kebidanan, 6(1), 211-224.

[2]. Hidayatullah, M.F. (2010). Pendidikan Karakter: Membangun Peradaban Bangsa. Education Policy, 11(1). 132-144.

[3]. Sumara, D. S., Humaedi, S., \& Santoso, M. B. (2017). Kenakalan remaja dan penanganannya. Prosiding Penelitian dan Pengabdian kepada Masyarakat, 4(2), 346-347.

[4]. Soemanto, R. B., \& Haryono, B. (2018). Kenakalan pelajar dalam keluarga single parent: Studi kasus pada pelajar dalam keluarga single parent di Sekolah Menengah Atas Negeri 1 Girimarto, Wonogiri Tahun 2012/2013. Jurnal Analisa Sosiologi, 4(2), 1-9.
[5]. Konishi, C., Miyazaki, Y., Hymel, S., \& Waterhouse, T. (2017). Investigating associations between school climate and bullying in secondary schools: Multilevel contextual effects modeling. School Psychology International, 38(3), 240-263.

[6]. Gini, G., Marino, C., Pozzoli, T., \& Holt, M. (2018). Associations between peer victimization, perceived teacher unfairness, and adolescents' adjustment and well-being. Journal of School Psychology, 67, 56-68.

[7]. Miller, W. B. (1958). Lower Class Culture as a Generating Milieu of Gang Delinquency. Journal of Social Issues, 14(3), 5-19.

[8]. Devlin, D. N., \& Gottfredson, D. C. (2018). The roles of police officers in schools: Effects on the recording and reporting of crime. Youth Violence and Juvenile Justice, 16(2), 208-223.

[9]. Suter, E. A., \& Norwood, K. M. (2017). Critical theorizing in family communication studies:(Re) reading relational dialectics theory 2.0. Communication Theory, 27(3), 290-308.

[10]. Durlak, J. A., Taylor, R. D., Kawashima, K., Pachan, M. K., DuPre, E. P., Celio, C. I., ... \& Weissberg, R. P. (2007). Effects of positive youth development programs on school, family, and community systems. American journal of community psychology, 39(3-4), 269-286.

[11]. Fitrah, M. (2017). Peran kepala sekolah dalam meningkatkan mutu pendidikan. Jurnal Penjaminan Mutu, 3(1), 31-42.

[12]. Rezkiyanto, I. (2016). Peran Keluarga, Masyarakat, dan Sekolah dalam Pendidikan. Jurnal Psikologi. 3(2). 151-166.

[13]. Gottfredson, G. D., Gottfredson, D. C., Payne, A. A., \& Gottfredson, N. C. (2005). School climate predictors of school disorder: Results from a national study of delinquency prevention in schools. Journal of research in crime and delinquency, 42(4), 412-444.

[14]. Fashiku, C. O. (2017). Effective Communication: any Role in Classroom Teaching-Learning Process in Nigerian Schools?. Bulgarian Journal of Science and Education Policy, 11(1), 171.

[15]. Pardimin, P., Arcana, N., \& Supriadi, D. (2019). Developing media based on the information and communications technology to improve the effectiveness of the direct instruction method in mathematics learning. Journal for the Education of Gifted Young Scientists, 7(4), 1311-1323.

[16]. Kurniawan, D. (2018). Komunikasi Model Laswell Dan Stimulus-Organism-Response Dalam Mewujudkan Pembelajaran Menyenangkan. Jurnal Komunikasi Pendidikan, 2(1), 60-68.

[17]. Asriati, N. (2012). Mengembangkan Karakter Peserta Didik Berbasis Kearifan Lokal Melalui Pembelajaran di Sekolah. Jurnal Pendidikan Sosiologi dan Humaniora, 3(2), 106-119.

[18]. Sulaiman, A. I. (2013). Model Komunikasi Formal dan Informal dalam Proses Kegiatan Pemberdayaan Masyarakat. Jurnal Penelitian Komunikasi, 16(2), 173-188.

[19]. Locker, K. O., \& Kienzler, D. S. (2013). Business and administrative communication. McGraw-Hill. 
[20]. Christensen, L. T., \& Svensson, E. (2017). The nature of strategic communication: A rejoinder to Nothhaft. International Journal of Strategic Communication, 11(3), 180-183.

[21]. Andreica, M. I., Sâmbotin, A. D., Drâguş, A., \& Ţăpuş, N. (2010, December). Towards a (multi-) usercentric stack of (multi-) point-to-(multi-) point communication services. In Proceedings of the 5th International Workshop on Enhanced Web Service Technologies (pp. 36-45).

[22]. DeVito, J. A., O'Rourke, S., \& O'Neill, L. (2000). Human communication. Longman.

[23]. Stead, B. A. (1972). Berlo's communication process model as applied to the behavioral theories of Maslow, Herzberg, and McGregor. Academy of Management Journal, 15(3), 389-394.

[24]. Denzin, N. K., \& Lincoln, Y. S. (2003). O involved in the study of social problems. Handbook of social problems: A comparative international perspective, 30.

[25]. Nisa, A. C., \& Wahid, U. (2014). Analisis Isi Kekerasan Verbal dalam Sinetron â€ œTukang Bubur Naik Haji The Seriesâ€ di RCTI (Analisis Isi Episode 396â€“407). Jurnal Komunikasi, 9(1), 85-102.
[26]. Saidi, A. (2009). Relasi Pancasila, Agama dan Kebudayaan: Sebuah Refleksi. Jurnal Masyarakat dan Budaya, 11(1), 25-50.

[27]. Hastasari \& Aw. (2018). Pola Komunikasi Keluarga dalam mencegah kenakalan pelajar SMA di Kota Yogyakarta. Informasi: Jurnal Ilmu Komunikasi FIS UNY, 48 (2), 231-243.

[28]. Wang, Y., Ki, E. J., \& Kim, Y. (2017). Exploring the perceptual and behavioral outcomes of public engagement on mobile phones and social media. International Journal of Strategic Communication, 11(2), 133-147.

[29]. Soffer, O. (2013). The internet and national solidarity: A theoretical analysis. Communication Theory, 23(1), 48-66.

[30]. Manaf, A. M. A., Taibi, M., \& Manan, K. A. (2017). Media agenda and public agenda: A study of issues during the 13th general election. Jurnal Komunikasi: Malaysian Journal of Communication, 33(2). 